\title{
Electrogenerative and related processes
}

\author{
Stanley H. Langer, John C. Card and Michael J. Foral \\ Chemical Engineering Department, University of Wisconsin-Madison \\ Madison, Wisconsin 53706
}

\begin{abstract}
A number of organic electrogenerative processes are described and explained by reviewing various aspects of studies associated with them. Electrogenerative hydrogenation, dehydrogenation, halogenation, and oxidation of alcohols are discussed together with possibilities for process improvement. Hydrogenation is used as a model for reviewing studies which correspond to the conventional ones of organic chemistry. The oxidation of ethanol vapor to acetaldehyde is used as an illustration of a potentially viable electrogenerative process. Generated electricity is a byproduct in electrogenerative processing and a useful indicator of the rate of reactant consumption. However, product selectivity may be lost where generation of high currents becomes the major consideration.
\end{abstract}

\section{INTRODUCTION}

Electrogenerative processes are those in which favorable thermodynamics are exploited together with requisite kinetic and mechanistic factors to produce a desired chemical while generating byproduct electricity. The concept of utilizing organic compounds to generate electricity is not new since löb suggested using nitro-compound reduction as a source of laboratory electricity in 1896 (1) and nitro compounds continue to be candidates for use as depolarizers in electrochemical cells and batteries. However, no product recovery has been envisioned. Related fuel cell applications also can be distinguished from electrogenerative processes since with the former maximum generation of power with complete combustion is the prime objective and little or no consideration is given to recovering products $(2,3)$. The "electrogenerative" designation emphasizes that chemical synthesis is the prime motivation and electricity is the byproduct.

Earlier possibilities for electrogenerative syntheses were recognized but few were developed beyond academic speculation or patent claims $(4,5)$. Now, the advances in fuel cell technology and electrocatalysis stimulated by the world energy and raw material situation provide some special opportunities for investigating electrosynthesis of organic chemicals not only without a power source but with concurrent electricity generation. Several reviews of potential electrogenerative processes are available (4-7) as well as recent pertinent discussions comparing conventional catalytic and electrocatalytic processes (8-11). All cite earlier examples and reviews. Here we explain and discuss electrogenerative processes, relate some to well known approaches used by organic chemists and indicate some recent developments. Much work has been directed toward identifying and exploring promising electrogenerative systems, as well as recognizing distinguishing features and applications. Some of these are introduced below. The long term goal is to add electrogenerative processing to the armamentarium of the organic chemist as well as the chemical industry.

Electrogenerative processes generally incorporate two coupled electrode reactions, an appropriate barrier electrolyte, provision for product recovery, and a circuit with load for using the electrical energy or possibly only dissipating it as shown in Figure 1. Apart from energy recovery, there are the possibilities of controlling reaction rate and cooling requirements for exothermic reactions as well as selectivity through potential and other electrocatalytic means. The term "electrogenerative" actually refers to favorable thermodynamics for an overall reaction; one is not precluded from using counter-electrode reactions other than those designated here, a potentiostat with another counter-electrode reaction and changing the electrolyte during operation. Developments have drawn on fuel cell technology but considerations associated with product recovery and reactor operation continue to emerge. Generally, electricity has minor value compared to the desired chemical. 


\section{DISCUSSION}

The hydrogenation of simple alkenes, conventionally a heterogeneous catalytic process, has served as an of -cited model system for investigating simple organic electrogenerative system operation $(5,12)$. Figure 1 shows a representative cell configuration. Hydrogen and unsaturated compounds react across the barrier electroly te phase (e.g. 2M aqueous perchloric acid) bounded by porous, electrolyte-impermeable gas-permeable catalytic electrodes. Detalls are given in several places (12-14). During operation, hydrogen ions formed at one electrode are eventually transferred through the electroly te while electrons are conducted through the external circuit. Hydrogenation occurs at the counter catalytic electrode at a controlled rate. With aqueous acid, overall electrode processes are

Anode:

$$
\mathrm{H}_{2}+2 \mathrm{H}^{+}+2 \mathrm{e}
$$

Various Transport Processes: $\mathrm{H}^{+}$(anode) $\rightarrow \mathrm{H}^{+}$(cathode)

Ca thode:

$$
\frac{\mathrm{RCH}=\mathrm{CHR}^{\prime}+2 \mathrm{H}^{+}+2 \mathrm{e}+\mathrm{RCH}_{2}-\mathrm{CH}_{2} \mathrm{R}^{\prime}}{\mathrm{RCH}=\mathrm{CHR}^{\prime}+\mathrm{H}_{2}+\mathrm{RCH}_{2}-\mathrm{CH}_{2} \mathrm{R}^{\prime}}
$$

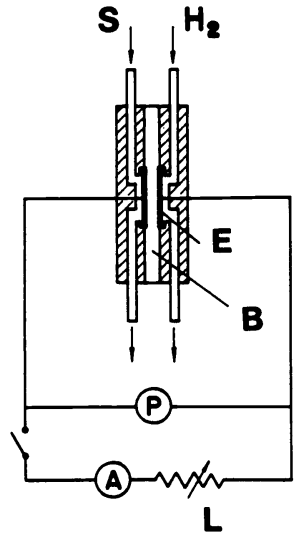

Fig. 1. Schematic representation of an electrogenerative cell and auxiliary equipment for studying hydrogenation

$S$, substrate;

$E$, electrodes;

$B$, barrier electroly te;

$P$, potentiometer;

A, ammeter;

$L$, variable resistive load

For testing and operating electrogenerative reactors as shown in Figure 1 , the external circuit load controls the rate (current) or electrode potential with excess electrode feed. Low solubility of reactants and products in the electrolyte or special separation is desired to limit direct chemical reactions, "chemical shorting" between the hydrogen and olefin reactants. The overall chemical reaction for the cell provides a basis for calculating a standard open circuit potential, $E^{\circ}$, for the cell

$$
\Delta G_{r}^{0}=-n F E^{0}
$$

where $\Delta G_{r}^{0}$ is the free energy change for the reaction. Table 1 presents some calculated open circuit potentials for electrogenerative reactions. The hydrogenation cell gives a characteristic reproducible open circuit voltage as shown in Table 1 despite the fact that the olefinic electrode is not considered reversible or operating at standard conditions. The olefinic electrode is positive relative to the reversible hydrogen electrode (RHE) whereas it would be expected to be negative in conventional electrolytic operation. Reactions 1 and 2 maintain a constant electrolyte composition even at significant current densities. Constant composition is not feasible at significant currents in potentiostatically controlled electrochemical cells without hydrogen supplied to the anode (15).

Electrogenerative systems lend themselves to studies analogous to some traditional approaches of organic chemistry. For example, isotope experiments can be performed with ethylene hydrogenation using a deuterated perchloric acid electrolyte, deuterium gas at the anode and labelled product and reactant analyses at the working cathode (16). Results show that several steps in the reaction sequence at the cathode are reversible leading to varying amounts of deuterium substitution in both the product ethane and ethylene. Kita and co-workers using a related approach have confirmed this, hydrogenating at positive potentials and expanding mechanistic studies in a number of ways (17). 
Table 1. Investigated and Attractive Electrogenerative Processes

\begin{tabular}{|c|c|c|c|c|c|}
\hline \multirow{2}{*}{$\begin{array}{l}\text { Overall Reaction } \\
\text { Reductions: }\end{array}$} & \multirow[t]{2}{*}{$\underline{\mathbf{n}}$} & \multirow{2}{*}{\multicolumn{2}{|c|}{$\frac{\Delta \mathrm{H}_{\mathrm{R}}^{\circ}}{(\mathrm{kca} 1 / \mathrm{mol})} \frac{\Delta \mathrm{G}_{\mathrm{R}}^{0}(298 \mathrm{~K})}{}$}} & \multirow[t]{2}{*}{$E^{0}(V)$} & \multirow{2}{*}{$\underline{E}_{0 b s} \stackrel{(V)}{(V)}$} \\
\hline & & & & & \\
\hline $\mathrm{C}_{2} \mathrm{H}_{4}+\mathrm{H}_{2}+\mathrm{C}_{2} \mathrm{H}_{6}$ & 2 & -32.7 & -24.1 & 0.522 & 0.505 \\
\hline $\mathrm{C}_{6} \mathrm{H}_{6}+3 \mathrm{H}_{2}+\mathrm{C}_{6} \mathrm{H}_{12}$ & 6 & -49.3 & -23.4 & 0.169 & 0.142 \\
\hline $\mathrm{C}_{2} \mathrm{H}_{3} \mathrm{~F}+\mathrm{H}_{2}+\mathrm{CH}_{3} \mathrm{CH}_{2} \mathrm{~F}$ & 2 & -38.0 & -24.5 & 0.530 & 0.50 \\
\hline $\mathrm{C}_{6} \mathrm{H}_{5} \mathrm{NO}_{2}+3 \mathrm{H}_{2}+\mathrm{C}_{6} \mathrm{H}_{5} \mathrm{NH}_{2}+2 \mathrm{H}_{2} \mathrm{O}(\ell)$ & 6 & -122.4 & -122.4 & 0.88 & - \\
\hline \multicolumn{6}{|l|}{ Halogenations: } \\
\hline $\mathrm{C}_{2} \mathrm{H}_{4}+\mathrm{Cl}_{2}+\mathrm{CH}_{2} \mathrm{ClCH}_{2} \mathrm{Cl}$ & 2 & -52.2 & -35.5 & 0.769 & 0.81 \\
\hline $\mathrm{C}_{2} \mathrm{H}_{4}+\mathrm{Cl}_{2}+\mathrm{H}_{2} \mathrm{O}+\mathrm{CH}_{2} \mathrm{ClCH}_{2} \mathrm{OH}+\mathrm{HCl}(\mathrm{aq})$ & 2 & $-46.7^{\star}$ & $-35.6^{*}$ & 0.742 & 0.81 \\
\hline $\mathrm{C}_{2} \mathrm{H}_{4}+\mathrm{Br}_{2}+\mathrm{CH}_{2} \mathrm{BrCH}_{2} \mathrm{Br}$ & 2 & $-23.3^{*}$ & $-21.2^{*}$ & 0.460 & 0.65 \\
\hline $\mathrm{C}_{2} \mathrm{H}_{4}+\mathrm{Cl}_{2}+\mathrm{F}^{-}+\mathrm{CH}_{2} \mathrm{ClCH}_{2} \mathrm{~F}+\mathrm{Cl}^{-}$ & 2 & $-41.9^{*}$ & $-34.2^{*}$ & 0.740 & 1.10 \\
\hline \multicolumn{6}{|l|}{ Oxidations: } \\
\hline $\mathrm{C}_{2} \mathrm{H}_{5} \mathrm{OH}+\frac{2}{2} \mathrm{O}_{2}+\mathrm{CH}_{3} \mathrm{CHO}+\mathrm{H}_{2} \mathrm{O}$ & 2 & -51.8 & -48.4 & 1.05 & 0.64 \\
\hline $\mathrm{C}_{2} \mathrm{H}_{5} \mathrm{OH}+\mathrm{O}_{2}+\mathrm{CH}_{3} \mathrm{COOH}+\mathrm{H}_{2} \mathrm{O}$ & 4 & -128.5 & -110.2 & 1.20 & 0.64 \\
\hline $\mathrm{CH}_{3} \mathrm{CHO}+\frac{1}{2} \mathrm{O}_{2}+\mathrm{CH}_{3} \mathrm{COOH}$ & 2 & -76.6 & -61.8 & 1.34 & - \\
\hline $\mathrm{C}_{2} \mathrm{H}_{5} \mathrm{OH}+3 \mathrm{O}_{2}+2 \mathrm{CO}_{2}+3 \mathrm{H}_{2} \mathrm{O}$ & 12 & -336.8 & -318.3 & 1.15 & 0.64 \\
\hline $\mathrm{CH}_{3} \mathrm{CHO}+\frac{5}{2} \mathrm{O}_{2}+2 \mathrm{CO}_{2}+2 \mathrm{H}_{2} \mathrm{O}$ & 10 & -285.0 & -269.9 & 1.17 & - \\
\hline $\mathrm{C}_{6} \mathrm{H}_{5}-\mathrm{CH}_{2} \mathrm{CH}_{3}+\frac{1}{2} \mathrm{O}_{2}+\mathrm{C}_{6} \mathrm{H}_{5} \mathrm{CHCH}_{2}+\mathrm{H}_{2} \mathrm{O}$ & 2 & $-40.2^{*}$ & $-47.1^{*}$ & 1.02 & - \\
\hline $\mathrm{C}_{2} \mathrm{H}_{4}+\frac{1}{2} \mathrm{O}_{2}+\mathrm{H}_{2} \mathrm{O} \rightarrow\left(\mathrm{CH}_{2} \mathrm{OH}\right)_{2}$ & 2 & -52.8 & -36.7 & 0.80 & - \\
\hline $\mathrm{CH}_{3} \mathrm{CHOHCH}_{3}+\frac{1}{2} \mathrm{O}_{2}+\left(\mathrm{CH}_{3}\right)_{2} \mathrm{CO}+\mathrm{H}_{2} \mathrm{O}$ & 2 & $-54.6^{*}$ & $-51.8^{*}$ & 1.123 & 0.68 \\
\hline
\end{tabular}

* estimated from group contributions

With constant ionic strength perchlorate electrolyte, it has been possible to study the bulk kinetics of ethylene electrogenerative hydrogenation at liquid impermeable Teflon-bonded, platinum black LAA-2 American Cyanamid commercial electrodes (13). Ethylene partial pressure or hydrogen ion concentration was maintained constant at a constant positive potential while the other was varied under conditions where transport was not limiting. An order in each reactant could be determined from

$$
\left(\frac{\partial \log 1}{\partial \log C_{j}}\right)_{T, E, C_{k \neq j}}=z_{j}
$$

with the assumption of a simple exponential rate expression. Here, 1 is current, $E$ is potential, C represents concentration of a specific reactant at the electrode, and $\mathrm{z}$ is
the order of reaction with respect to each reactant (13).

The general kinetic rate equation fitting our experimental results at intermediate currents $\left(u 0.5 \mathrm{~mA} / \mathrm{cm}^{2}\right)$ had the form

$$
i=n F k_{0} P_{C_{2} H_{4}}^{0} C_{H^{+}}^{2} \exp (-2 E F / R T)
$$

The rate constant at zero potential, $k_{0}$, depends on temperature in an Arrhenius type relation. The conventional rate constant is replaced by $k_{0} e^{-2 E F / R T}$ to take into account the potential dependence of the rate in electrochemical reactions. Some $k$ inetic parameters are presented in Table 2. From equations of the form of Equation 6 and the data of Table 2, the effect of temperature change or voltage change at constant temperature can be evaluated. For a change in temperature of $20^{\circ} \mathrm{C}$, with an effective activation energy of 2.5 kcals currents would increase by a factor of 1.3 . For a $0.2 \mathrm{~V}$ change the calculated current would increase by a factor of $5.7 \times 10^{6}$. However mass transfer and cell internal resistance eventually play a limiting role. The Tafel slope value of $0.035 \mathrm{~V}$ also can be interpreted $(13,17,18)$. 
Table 2. Kinetic Parameters for Ethylene Hydrogenation over $P$ latinum and Palladium Black at Positive Potentials, $\mathrm{HClO}_{4}$ electroly te

\begin{tabular}{|c|c|c|}
\hline Parame ter & Pt (13) & Pd (20) \\
\hline Tafel slope (v) & 0.035 & 0.033 \\
\hline Reaction order in $\mathrm{H}^{+}$ & 1.9 & 1.8 \\
\hline Reaction order in $\mathrm{C}_{2} \mathrm{H}_{4}$ & 0.1 & 0 \\
\hline$\underset{(\text { kcal/mole })}{\operatorname{Apparent} \mathrm{E}_{\mathrm{a}}}($ at $0.17 \mathrm{~V})$ & 2.5 & - \\
\hline $\begin{array}{l}\text { Rate constant, } k_{0}, \\
\left(\mathrm{~cm}^{4} \mathrm{~mole}^{-1} \mathrm{sec}^{-1}\right)\end{array}$ & $8.0 \times 10^{-4}$ & $1 \times 10^{5}$ \\
\hline $\begin{array}{l}\text { Standard exchange current } \\
\text { density, } 1_{O},\left(\mathrm{~A} / \mathrm{cm}^{2}\right)^{\star}\end{array}$ & $1.9 \times 10^{-13}$ & $3 \times 10^{-6}$ \\
\hline
\end{tabular}

* Based on unit concentrations of reactants, $1_{0}=n F k_{0} \exp \left(-\alpha E^{\circ} F / R T\right)$.

Table 3. Comparison of Observed and Calculated Distribution of Deuterated Products from Ethy lene and Deuterium in Electrogenerative Reaction with $\mathrm{D}_{2} \mathrm{O}-2 \mathrm{~N}$ Perchloric Acid-d, Electroly te (16)

\begin{tabular}{llc}
\hline Sample & A & B \\
Eobs $(V)$ & 0.219 & 0.044 \\
I (mA) & 5.3 & 265 \\
\% Conversion & 1.04 & 49.4
\end{tabular}

\begin{tabular}{|c|c|c|c|c|}
\hline E thy lene & Ca lc. & Obs. & Calc. & Obs. \\
\hline$d_{1}$ & $\overline{33.5}$ & $\overline{34.4}$ & 8.2 & $\overline{6.6}$ \\
\hline$d_{2}$ & 19.1 & 11.8 & 4.9 & 3.0 \\
\hline$d_{3}$ & 8.1 & 8.7 & 1.8 & 1.6 \\
\hline$d_{4}$ & 1.9 & 6.0 & 0.3 & 0.6 \\
\hline
\end{tabular}

\begin{tabular}{crrrr} 
Ethane & & & & \\
\hline $\mathrm{d}_{0}$ & 2.1 & 5.6 & 15.9 & 17.9 \\
$\mathrm{~d}_{1}$ & 10.0 & 7.4 & 29.2 & 26.5 \\
$\mathrm{~d}_{2}$ & 12.5 & 9.0 & 22.8 & 18.8 \\
$\mathrm{~d}_{3}$ & 7.6 & 6.8 & 12.1 & 11.0 \\
$\mathrm{~d}_{4}$ & 3.7 & 4.9 & 4.0 & 8.4 \\
$\mathrm{~d}_{5}$ & 1.3 & 3.7 & 0.7 & 4.3 \\
$\mathrm{~d}_{6}$ & 0.2 & 1.8 & 0.04 & 1.1
\end{tabular}

The kinetic results agree with the mechanism postulated from the tracer study with deuterated perchloric acid electrolyte and unlabelled ethylene (16). The electrogenerative reaction is uniquely suited to tracer studies; the deuterium gas per se never comes in contact with ethylene over catalyst. At open circuit ethane is not produced nor is there any labelled ethylene. A Kemball model was used to interpret and predict the results from an operating cell some of which are shown in Table 3 . The data support a mechanism involving a number of reversible steps which can be represented by

$$
\begin{gathered}
2 \sigma+\mathrm{C}_{2} \mathrm{H}_{4}(g) \neq \sigma_{2}\left[\mathrm{C}_{2} \mathrm{H}_{4}\right] \\
\text { or } \quad \sigma_{2}\left[\mathrm{C}_{2} \mathrm{H}_{4}\right]+\mathrm{H}^{+}+e \neq \sigma\left[\mathrm{C}_{2} \mathrm{H}_{5}\right]+\sigma \\
\sigma_{2}\left[\mathrm{C}_{2} \mathrm{H}_{4}\right]+\mathrm{H} \neq \sigma\left[\mathrm{C}_{2} \mathrm{H}_{5}\right]+\sigma \\
\sigma+\mathrm{H}^{+}+e \neq \sigma[\mathrm{H}] \\
\sigma\left[\mathrm{C}_{2} \mathrm{H}_{5}\right]+\sigma[\mathrm{H}] \stackrel{\text { r.d.s. }}{\longrightarrow} \mathrm{C}_{2} \mathrm{H}_{6}+2 \sigma
\end{gathered}
$$

where $\sigma$ represents a site and the rate determining step is ( $V$ ). The selectivity for deuterium in the first addition was high. Related mechanisms also have been postulated by Hubbard, et al. (18). Indeed, the hydrogenation of ethylene and unsaturated hydrocarbons at positive electrogenerative potentials has been the subject of a number of studies ( 10 , 17,18 ) because this is one of the few reactions that takes place heterogeneously and electrochemically. However, despite its value for model studies $(16,17,19,20)$, hydrogenation of unsaturated hydrocarbons has been of limited interest for long term development.

\section{HALOGENATION}

Electrogenerative oxidations as halogenations occur to give dihaloalkanes and haloalcohols with aqueous halide electrolytes $(14,21,22)$. For electrogenerative chlorination with chloride electrolyte, platinum black electrode reactions are:

$$
\begin{aligned}
& \text { Ca thode: } \mathrm{Cl}_{2}+2 \mathrm{e}+2 \mathrm{Cl}^{-} \\
& \text {Anode: } \mathrm{RCH}=\mathrm{CHR}^{\prime}+2 \mathrm{Cl}^{-}+2 \mathrm{e}+\left.\mathrm{RCH}^{-\mathrm{CHR}}\right|_{\mathrm{Cl}} ^{\mathrm{Cl}} \\
& \mathrm{RCH}=\mathrm{CHR}^{\prime}+2 \mathrm{Cl}^{-}+\mathrm{H}_{2} \mathrm{O}+2 \mathrm{e}+\mathrm{RCH}-\mathrm{CHR}
\end{aligned}
$$

The open circuit potential with ethylene is about $0.81 \mathrm{~V}$ compared to a calculated value of $0.77 \mathrm{~V}$. The platinum black catalyzed chlorine cathode operates close to the reversible standard potential of $1.36 \mathrm{~V}$. Thus the chlorinating anode at open circuit is at a 


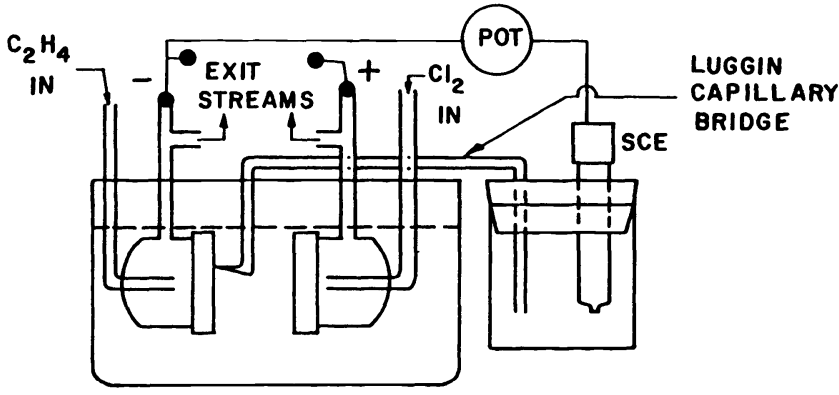

Fig. 2. Schematic of simulated electrogenerative e thy lene-chlorine cell with Luggin capillary and reference electrode for measuring anode polarizations (Reference 22 explains details)

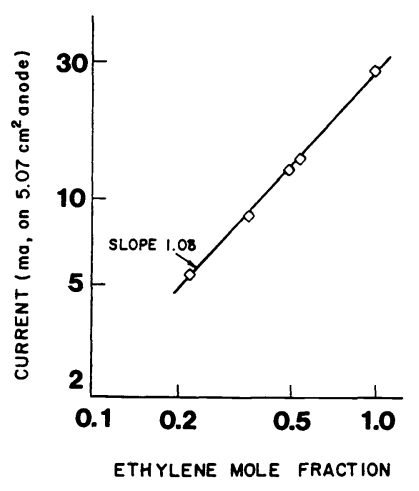

Fig. 3. Illustrative plot of electrogenerative chlorination rate dependence on ethylene partial pressure $1 \mathrm{M}$ aqueous $\mathrm{NaCl}, 1 \mathrm{M} \mathrm{NaClO} 4$ electroly te. LAA-1 a node, platinum foil cathode, $\mathrm{E}_{\text {Anode }}=1.0875 \mathrm{~V}$ (vs. SCE)

potential somewhat above $0.5 \mathrm{~V}$. While the potential rises on operation, the chloride ion is discharged below the standard chlorine potential and considerably below the potential of conventional electrochemical chlorination where power is supplied. other values for halogenation reactions are compared in Table 1 .

Electrogenerative chlorination shows a strong dependence of total reaction rate on both reactant concentrations, with no corresponding dependence of the selectivity for the co-products on composition (21-23). To study halogenation kinetics a simulated electrogenerative cell with reference electrode, as represented in Figure 2, was devised and operated in our laboratories $(22,23)$. The steady state polarization was determined as a function of current density for a range of chloride ion concentrations and ethylene partial pressures. Results of experiments on ethylene dependence are illustrated in Figure 3 . The current, 1 , could be correlated assuming separability of variables with the expression

$$
1 \propto \mathrm{P}_{\mathrm{C}_{2} \mathrm{H}_{4}}\left[\mathrm{Cl}^{-}\right] \mathrm{f}(n)
$$

Here, $\mathrm{P}_{\mathrm{C}_{2} \mathrm{H}_{4}}$ is the ethylene partial pressure in the nitrogen gas phase, [C1-] is the bulk chloride ion concentration (total lonic strength was maintained constant using $\mathrm{NaClO}_{4}$ supporting aqueous electrolyte) and $f(\eta)$ describes the dependence of the current density on the anode overpotential and should take the form of Equation 6 . Correlation of current density at constant anode potential in the region around $+1.25 \mathrm{~V}$ (vs. SHE) showed the exponents were unity \pm 0.1 at the $99 \%$ confidence level. This correlation extended over the concentration range $0.25 \underline{M}<\left[\mathrm{Cl}^{-}\right]<2.0 \underline{\mathrm{M}}$ and $0.2 \mathrm{~atm}<\mathrm{p}_{\mathrm{C}_{2} \mathrm{H}_{4}}<1.0 \mathrm{~atm}$. Other

experiments and calculations showed that transport limitations played no role in these results $(22,23)$.

It is generally believed (24a) that the surface of platinum is saturated with chloride at low anode potentials $(\sim 0.6 \mathrm{~V}$ vs. SHE) in concentrated chloride electrolytes (24b). Thus the platinum surface not covered by ethylene can be considered saturated with chloride, so that the surface coverage with chloride is independent of chloride concentration. It can be hypothesized that the first order dependence on chloride ion concentration implies a rate determining step (r.d.s.) involving discharging a chloride ion from the electrolyte. The observed first order dependence on ethylene partial pressure can be interpreted in terms of an r.d.s. involving adsorbed ethylene obeying a linear adsorption isotherm. The crucial electrocatalytic role of the electrode material indicates that the r.d.s. occurs on the surface. An activation energy of less than $1 \mathrm{kca} / \mathrm{mole}$ at temperatures in the range of $20-50^{\circ} \mathrm{C}$ at higher potentials $(1.06 \mathrm{~V})$ was consistent with the involvement of adsorbed species in the rate determining step. Current densities of the order of $15-20 \mathrm{ma} / \mathrm{cm}^{2}$ were obtained. 
The anode reaction can be postulated to occur by the following mechanism

$$
\begin{aligned}
& \mathrm{C}_{2} \mathrm{H}_{4}(\mathrm{ads})+\mathrm{Cl}^{-}+\mathrm{C}_{2} \mathrm{H}_{4} \mathrm{Cl}^{*}+e \\
& \mathrm{C}_{2} \mathrm{H}_{4} \mathrm{Cl}^{*}+\mathrm{Cl}^{-}+\mathrm{CH}_{2} \mathrm{ClCH}_{2} \mathrm{Cl}+\mathrm{e} \\
& \mathrm{C}_{2} \mathrm{H}_{4} \mathrm{Cl}^{*}+\mathrm{H}_{2} \mathrm{O}+\mathrm{CH}_{2} \mathrm{ClCH}_{2} \mathrm{OH}+\mathrm{H}^{+}+e
\end{aligned}
$$

with Reaction 11 being rate determining. The starred formula represents the reactive surface bonded intermediate believed to form at a catalytic site. The dichloride predominates at lower anode potentials. With increased current drain and higher anode potentials chlorohydrin becomes the major product.

The postulated species $\mathrm{C}_{2} \mathrm{H}_{4} \mathrm{Cl}^{*}$ apparently is so reactive that fluoride ion can be discharged from aqueous solution. With 2 molar fluoride ion in the chloride electrolyte about $4 \% 1$ chloro-fluoro-ethane is formed from aqueous solution (25).

\section{CONTROL OF SELECTIVITY; ELECTROCATALYSIS AND POTENTIAL}

The halogenation mechanism can be further related to organic practice when it is noted that graphite is an adequate anode catalyst in the formation of bromine analogs with a bromine or even chlorine cathode and bromide electrolyte (26). Thus the platinum catalyst at the anode can be replaced with graphite. Since propylene bromohydin can be dehydrobrominated with base to give propylene oxide, the anode reaction below is of interest:

$$
\mathrm{CH}_{3} \mathrm{CH}_{2}=\mathrm{CH}_{2}+2 \mathrm{Br}^{-}+\mathrm{H}_{2} \mathrm{O}+\mathrm{CH}_{3} \mathrm{CHOHCH}_{2} \mathrm{Br}+\mathrm{HBr}
$$

The electrogenerative reduction of benzene and derivatives in a system similar to Figure 1 using a wetted $\left(3 \mathrm{~N} \mathrm{HClO}_{4}\right)$ filter paper matrix gives some idea of possible control of selectivity with aromatic compounds (27). Benzene is reduced readily to cyclohexane at positive potentials close to those calculated on a thermodynamic basis (see Table 1) in contrast to the special conditions needed for cathodic reduction including extreme negative potentials. On the other hand, toluene is reduced at about one-quarter of this rate on platinum black electrodes. Fluorobenzene vapor is reduced to give a product containing equal parts benzene and cyclohexane suggesting some possible development for selective cleavage of halogen substituents from aromatic rings.

The possibilities for selective reduction processes are more dramatically illustrated by comparing the electrogenerative reduction of vinyl fluoride using platinum and palladium black catalysts operating against a hydrogen anode (28). All of the following reactions can be favored at the cathode.

$$
\begin{aligned}
& \mathrm{CH}_{2}=\mathrm{CHF}+2 \mathrm{H}^{+}+2 e+\mathrm{CH}_{3}-\mathrm{CH}_{2} \mathrm{~F} \\
& \mathrm{CH}_{2}=\mathrm{CHF}+2 \mathrm{H}^{+}+2 e+\mathrm{CH}_{2}=\mathrm{CH}_{2}+\mathrm{HF} \\
& \mathrm{CH}_{2}=\mathrm{CH}_{2}+2 \mathrm{H}^{+}+2 e+\mathrm{C}_{2} \mathrm{H}_{6}
\end{aligned}
$$

With platinum catalyzed reduction carbon-fluorine cleavage occurs with ethylene formation favored at higher potentials $(\sim 0.2 \mathrm{~V})$ and ethane at lower potentials $(\sim 0.1 \mathrm{~V})$. Selectivity control with potential on palladium is illustrated in Figure 4; it can be seen that whereas carbon-fluorine cleavage is favored at higher potentials, an eighty percent selectivity for

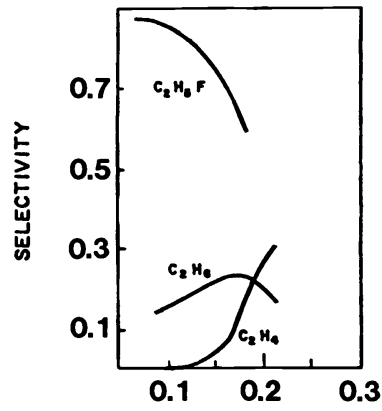

IR-FREE VOLTAGE (volts)
Fig. 4. Product variation with potential from electrogenerative hydrogenation of vinyl fluoride; saturated filter paper; matrix cell; $2 \mathrm{~N} \mathrm{HClO}_{4}$ electrolyte; palladium cathode 
reduction to ethyl fluoride can be achieved by simply reducing the cell voltage, a parameter not available in conventional heterogeneous catalysis. In simple electrogenerative hydrogenation, palladium gives greater currents than platinum at all voltages $(20)$.

\section{PROCEDURES AND CONDITIONS}

While explaining and emphasizing special features of electrogenerative processes we have not addressed special considerations and features of cell operation which will be important if we are to place electrogenerative cell operation into the domain of the organic chemist. Both free energies and heats of reaction must be considered for analysis $(5-7)$. Since

$$
\Delta G_{R}^{0}=\Delta H_{R}^{0}-T \Delta S
$$

the maximum amount of electrical energy recoverable is diminished by $T \Delta S$. Some idea of the highest possible recovery of heat as electricity can be obtained from comparing $\Delta G^{\circ}{ }_{R}$ and $\Delta \mathrm{H}^{\circ}$ values in Table 1 .

The maximum thermodynamic efficiency, $\varepsilon$, and the generated cell voltage, $E_{c}$, are

$$
\varepsilon=\Delta G^{\circ} / \Delta \mathrm{H}^{\circ} \quad(19) ; \quad \mathrm{E}_{c}=\mathrm{E}_{\mathrm{m}}+\mathrm{IR}_{1}
$$

where $E_{m}$ is the measured cell voltage, I the total cell current and $R_{1}$ is the cell electrolyte resistance. For maximum $E_{m}$, it is desirable to have the thinnest possible electrolyte barrier compatible with separation of reactants. Not only can ion-exchange membranes be used as barrier electrolytes, but it is even possible that metal deposited on solid polymer electrolytes might serve as electrodes (29). Possibilities for non-aqueous electrolytes are intriguing and developments should come in the future.

Both the cathode and the anode potential can be affected by activation polarization as well as other potential losses associated with irreversibility. The oxygen electrode frequently gives a rest potential loss of about $0.17 \mathrm{~V}$ at open circuit.

The catalysts used here are in the form of metal powder. With process development the substitution of graphite or other carbons for metal supports are anticipated. To evaluate production possibilities it can be noted that for a 2 electron change, a current density of $50 \mathrm{ma} / \mathrm{cm}^{2}$ would give slightly less than $1 \mathrm{~m}$ Mole per hour. For a small laboratory size reactor of $100 \mathrm{~cm}^{2}$, production would be about $0.1 \mathrm{~mole} / \mathrm{hour}$ while an electrode area of one square meter would give 9.3 moles/hour.

\section{Electrogenerative catalytic vs. conventional catalytic processes}

While the role of electrocatalysis is now well recognized in electrochemical processing generally, it is particularly important in electrogenerative processing. Comparisons are of ten made in terms of gas-solid (conventional heterogeneous catalysis), versus liquid-solid (electrochemical catalysis). Space here permits only a brief acknow ledgement of this important aspect discussed elsewhere (5,9-11). It can be noted that conventional catalytic hydrogenation can be conjectured to take place by a process analogous to electrogenerative hydrogenation. However, recent results (18) indicate that this is probably not a completely valid analogy since heterogeneous catalysis takes place on a carbonaceous residue while electrogenerative hydrogenation occurs at the metal surface. The analogy appears to be more valid for electrogenerative nitric oxide reduction $(7,8)$, an inorganic process.

\section{OXIDATION}

The high free energy change for many oxidation reactions endows special appeal to them for electrogenerative processing. However, the problem is that ordinarily when a bond break occurs in a hydrocarbon species on the catalyst, the species is oxidized completely. Unfortunately although the fuel cell oxidation of alcoholic species frequently is incomplete this process is difficult to control.

Dehydrogenation in certain instances would be of value and has been considered experimentally for the anodic conversion of ethylbenzene to styrene $(30)$.

$$
\mathrm{C}_{6} \mathrm{H}_{5} \mathrm{CH}_{2} \mathrm{CH}_{3}+\mathrm{C}_{6} \mathrm{H}_{5} \mathrm{CH}=\mathrm{CH}_{2}+2 \mathrm{H}^{+}+2 e
$$

The cathode would be an oxygen electrode. This reaction has been performed using the solid s tate electrolyte, $\mathrm{ZrO}_{2}\left(\mathrm{Y}_{2} \mathrm{O}_{3}\right)$, at high temperatures (of the order of $600^{\circ} \mathrm{C}$ ) and platinum paste electrodes. Currents of the order of $1-3 \mathrm{~mA} / \mathrm{cm}^{2}$ are obtained but the principal problem appears to be selectivity. In addition to a parallel oxidation to give carbon dioxide there is a chemical cracking reaction. Whether or not this process with a solid state electrolyte is ultimately successful, Michaels and Vayenas discuss interesting approaches for limiting complete oxidation (30). 


\section{Alcohol oxidation}

With long term attention turning to biomass based economies, the oxidation of alcohols to aldehydes or ketones assumes new importance. Acetaldehyde, the product of ethanol oxidation, is of special interest since it can be utilized in the synthesis of other basic chemicals such as acetic acid, butanol, etc. Possibilities were recognized earlier and these are referenced in a previous paper (31) as well as a patent issued to Meshbesher (32). Here, the oxidation of ethanol and isopropanol can be illustrative. The ethanol oxidation cell and reactions can be represented by

$$
\begin{aligned}
& \text { Pt, } \mathrm{C}_{2} \mathrm{H}_{5} \mathrm{OH}\left|\mathrm{H}^{+}, \mathrm{H}_{2} \mathrm{O}\right| \text { Ion Exchange Membrane }\left|\mathrm{H}^{+}, \mathrm{H}_{2} \mathrm{O}\right| \mathrm{O}_{2}, \mathrm{Pt} \\
& \text { Anode }(-): \quad 2 \mathrm{C}_{2} \mathrm{H}_{5} \mathrm{OH}+2 \mathrm{CH}_{3} \mathrm{CHO}+4 \mathrm{H}^{+}+4 \mathrm{e} \\
& \text { Cathode (+): } \mathrm{O}_{2}+4 \mathrm{H}^{+}+4 \mathrm{e}+2 \mathrm{H}_{2} \mathrm{O}
\end{aligned}
$$

This process can be operated with cells described earlier using alcohol dissolved in the acid liquid electrolyte or an alcohol containing vapor stream discussed recently ( 31 ). Our present choice involves the latter and a cation-exchange membrane (RAI 4010) as a separator for an acid electrolyte phase $7 \mathrm{~mm}$ in thickness. The modification of the cell of Figure 1 is illustrated in Figure 5 which incorporates a provision for changing electrolyte. The vapor feed is obtained by bubbling nitrogen through various concentrations of alcohol-water mixtures before introduction to the anode compartment at the electrode backing. The transport of reactant vapor through the backing to the anode catalyst-solution interface followed by vaporization of product aldehyde back through the porous backing appears to be advantageous. Evidently acetaldehyde can be recovered before there is appreciable mixing with electrolyte.

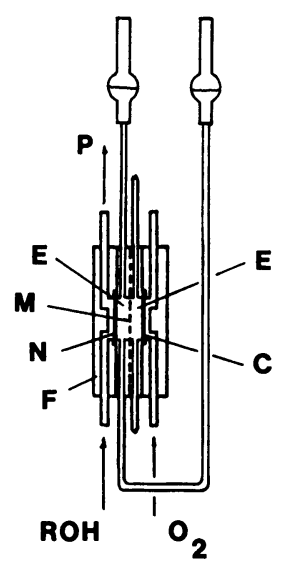

Fig. 5. Schematic of divided, free electrolyte, oxidation cell showing electrolyte reservoirs (only anode reservolr shown);

$P$, oxidation product vapor effluent;

E, electroly te chambers;

$M$, cationic membrane;

$\mathrm{N}$, anode;

C, cathode;

F, cell face-plates with gas inlets.

Operation with aqueous ethanol is attractive because it can circumvent the distillation problem ordinarily involved in separating alcohol from water. Separation of product acetaldehyde from the effluent at the anode compartment would be facilitated by the low boiling point of acetaldehyde $\left(20.2^{\circ} \mathrm{C}\right)$ relative to ethanol and water. Furthermore there can be ethanol enrichment in the vaporization process for the anode feed because of higher ethanol vapor pressures relative to water. In earlier work with American Cyanamid LAA-25 electrodes ( $25 \mathrm{mgm} \mathrm{Pt} / \mathrm{cm}^{2}$ ) we showed that conversions of the order of $\mathrm{fifty}$ percent or higher could be achieved and that feed from twenty-five volume percent ethanol solutions at room temperature was preferable to feed from pure ethanol (31). Qualitatively, this superior performance can be rationalized by consideration of the need for aqueous solvation of the protons formed at the catalyst-electrolyte interface as represented in Equation 22.

It was of interest to experiment with the performance of lighter loaded American Cyanamid LAA-2 electrodes ( $9 \mathrm{mgm} \mathrm{Pt} / \mathrm{cm}^{2}$ ). These electrodes also incorporate a $0.15 \mathrm{~mm}$ layer of porous catalytic platinum-black Teflon supported on tantalum screen backed with a porous Teflon layer of comparable thickness. Analyses of inlet and outlet streams were performed as described earlier (31). Pertinent data from experiments with LAA-2 electrodes a re summarized in Table 4 . 


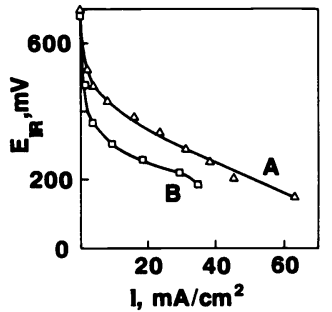

Fig. 6. Polarization curves with LAA-2

platinum black electrodes. Oxygen cathode, alcohol vapor in nitrogen

at anode, $E$ is IR corrected.

Curve A: 75-25 (v/v) ethanol-water in vaporizer, Exp. I in Table 4;

Curve B: $100 \%$ 2-propanol in vaporizer, Exp. II in Table 4.

The performance of the LAA-2 electrodes in terms of current generation capacity is represented by Curves $A$ and $B$ in Figure 6. These polarization curves are for slightly heated ethanol at $36^{\circ} \mathrm{C}$ fed to a cell at $38^{\circ} \mathrm{C}$ and for isopropanol dehydrogenation at $20^{\circ} \mathrm{C}$, Curve $B$. In both instances $3 \mathrm{M}$ sulfuric acid was the electrolyte. Illustrative experimental results are presented in Table 4. From Experiment II it can be seen that substantial production of acetone from 2-propanol dehydrogenation occurs with less than ten percent of the converted alcohol oxidized to carbon dioxide. The oxidation to carbon dioxide does provide significant current. Pertinent references to earlier work on isopropy 1 alcohol oxidation to acetone in solution are found in the report of Rao and Roy (33). Experiment I of Table 4 corresponding to Curve A of Figure 6 illustrates the relatively high currents

Table 4. Selected data for oxidation of ethanol (or other alcohol) vapor on LAA-2 platinum black electrodes $\left(5 \mathrm{~cm}^{2}\right)$ with $3 \mathrm{M} \mathrm{H}_{2} \mathrm{SO}_{4}$ electrolyte in divided cell

\begin{tabular}{|c|c|c|c|c|c|c|c|c|c|c|c|}
\hline $\begin{array}{l}\text { Experiment } \\
\text { (Sa turator) }\end{array}$ & $\begin{array}{c}R \\
(\Omega)\end{array}$ & $\underset{(c c / m i n)}{F}$ & $\begin{array}{c}\text { Ce11 T } \\
\left({ }^{\circ} \mathrm{C}\right)\end{array}$ & $\begin{array}{c}\mathrm{N}_{\mathrm{E}} \\
\left(10^{-5_{\mathrm{mol}}} \mathrm{m}\right. \\
\mathrm{min})\end{array}$ & $\underset{(\mathrm{mV})}{\mathrm{E}}$ & $\begin{array}{l}\mathrm{I} \\
(\mathrm{mA} / \\
\left.\mathrm{cm}^{2}\right)\end{array}$ & $\begin{array}{c}{ }_{\mathrm{A}}^{\mathrm{N}_{\mathrm{A}}} \\
\underset{\mathrm{min})}{\left(10^{-5_{\mathrm{mol}}}\right)}\end{array}$ & $\mathrm{x}_{\mathrm{A}}$ & $\mathrm{x}_{\mathrm{CO}_{2}}$ & $\begin{array}{l}{ }_{A} A \\
(\%)\end{array}$ & $\begin{array}{l}{ }^{\mathrm{A}} \mathrm{CO} \\
(\%)\end{array}$ \\
\hline \multirow[t]{2}{*}{$\stackrel{\text { I }}{(75 \% \text { EtOH,H })}$} & 0.22 & 39 & 38 & 9.8 & $\begin{array}{l}382 \\
288\end{array}$ & $\begin{array}{l}16 \\
31\end{array}$ & $\begin{array}{l}0.8 \\
2.7\end{array}$ & $\begin{array}{l}.09 \\
.27\end{array}$ & $\begin{array}{l}.01 \\
.02\end{array}$ & $\begin{array}{l}33 \\
55\end{array}$ & $\begin{array}{l}24 \\
22\end{array}$ \\
\hline & & & & & 204 & 45 & 4.2 & .43 & .01 & 59 & 10 \\
\hline \multirow[t]{2}{*}{$\begin{array}{l}\operatorname{II}^{a} \\
\left(100^{a}\right)\end{array}$} & 0.29 & 30 & 20 & $7.8^{a}$ & $\begin{array}{l}366 \\
256\end{array}$ & $\begin{array}{r}4 \\
19\end{array}$ & $\frac{0.3^{a}}{1.1}$ & $\frac{.04^{\mathrm{a}}}{.13}$ & $\begin{array}{r}0 \\
.01\end{array}$ & ${\frac{52^{a}}{36}}^{a}$ & $\begin{array}{r}9 \\
19\end{array}$ \\
\hline & & & & & 219 & 29 & 1.6 & .20 & .02 & 34 & 28 \\
\hline \multirow{3}{*}{$\begin{array}{l}\text { III }{ }^{\mathrm{b}} \\
\text { Ethanol }\end{array}$} & 0.27 & 37 & 26 & 24 & 414 & 2 & 0.1 & - & - & 16 & 0 \\
\hline & olved & in elect & oly te & & 237 & 16 & 0.7 & b & b & 28 & 0 \\
\hline & & & & & 137 & 23 & 0.7 & - & - & 19 & 0.2 \\
\hline \multirow{2}{*}{$\begin{array}{l}\text { IV } \\
(75 \% \text { E tOH })\end{array}$} & 0.22 & 39 & 38 & 7.1 & $\begin{array}{l}385 \\
316\end{array}$ & $\begin{array}{l}24 \\
46\end{array}$ & $\begin{array}{l}0.9 \\
1.8\end{array}$ & .12 & .04 & 23 & 42 \\
\hline & & & & & 166 & 72 & 1.4 & .19 & .09 & 12 & 33 \\
\hline \multirow[t]{2}{*}{$\begin{array}{l}\mathrm{V} \\
(75 \% \mathrm{EtOH})\end{array}$} & 0.22 & 59 & 38 & 12 & $\begin{array}{l}395 \\
295\end{array}$ & $\begin{array}{l}17 \\
39\end{array}$ & $\begin{array}{l}0.7 \\
2.5\end{array}$ & $\begin{array}{l}.06 \\
.22\end{array}$ & $\begin{array}{l}.01 \\
.02\end{array}$ & $\begin{array}{l}26 \\
42\end{array}$ & $\begin{array}{l}28 \\
18\end{array}$ \\
\hline & & & & & 160 & 68 & 3.2 & .28 & .04 & 30 & 23 \\
\hline \multirow[t]{2}{*}{$\begin{array}{l}\text { VI } \\
(75 \% \text { EtOH,H })\end{array}$} & 0.22 & 59 & 38 & 14 & $\begin{array}{l}407 \\
273\end{array}$ & $\begin{array}{r}9 \\
32\end{array}$ & $\begin{array}{l}0.5 \\
3.1\end{array}$ & $\begin{array}{l}.03 \\
.22\end{array}$ & $\begin{array}{r}0 \\
.01\end{array}$ & $\begin{array}{l}36 \\
63\end{array}$ & $\begin{array}{l}23 \\
14\end{array}$ \\
\hline & & & & & 143 & 61 & 5.9 & .41 & .01 & 61 & 12 \\
\hline $\begin{array}{l}\text { VII } \\
(50 \% \text { EtOH,H })\end{array}$ & 0.25 & 64 & 38 & 14 & $\begin{array}{l}290 \\
167\end{array}$ & $\begin{array}{l}33 \\
63\end{array}$ & $\begin{array}{l}2.8 \\
5.9\end{array}$ & $\begin{array}{l}.20 \\
.43\end{array}$ & $\begin{array}{l}.01 \\
.01\end{array}$ & $\begin{array}{l}55 \\
59\end{array}$ & $\begin{array}{r}10 \\
9\end{array}$ \\
\hline $\begin{array}{l}\text { VIII } \\
(25 \% \text { EtOH,H })\end{array}$ & 0.23 & 59 & 37 & 8.7 & $\begin{array}{l}389 \\
330\end{array}$ & $\begin{array}{l}20 \\
39\end{array}$ & $\begin{array}{l}0.8 \\
1.4\end{array}$ & $\begin{array}{l}.09 \\
.16\end{array}$ & $\begin{array}{l}.02 \\
.04\end{array}$ & $\begin{array}{l}25 \\
23\end{array}$ & $\begin{array}{l}31 \\
36\end{array}$ \\
\hline
\end{tabular}

$N_{E}$ - Molar flow rate of ethanol; $N_{A}$ - Molar flow rate of acetaldehyde in anodic effluent;

$\mathrm{X}_{\mathrm{A}}$ - Conversion to acetaldehyde in product effluent relative to ethanol feed; $\mathrm{A}_{\mathrm{A}, \mathrm{CO}_{2}-}$

$\mathrm{H}$ indicates feed saturator heated to $36^{\circ} \mathrm{C}$.

a. $100 \%$ isopropanol feed, $N_{A}, X_{A}$ and $A_{A}$ refer to acetone; $N_{E}$ refers to isopropanol

b. $1 \mathrm{M}$ ethanol dissolved in anoly te (feed vaporizer not used) 
and selectivity for acetaldehyde formation that can be obtained in ethanol oxidation. The results of other experiments illustrated in Table 4 provide some guidance for developing cell operations. The data for ethanol conversion to acetaldehyde are encouraging since conversions of 0.4 or higher are achieved in several experiments. It can be noted from Experiments IV, $V$ and VIII that there is an optimum cell voltage for selective aldehyde production. At lower cell voltages (higher ethanol electrode potentials) and higher currents greater conversions to byproduct carbon dioxide occur relative to acetaldehyde. Thus, electrogenerative cells cannot be operated at higher currents without consideration of losses in selectivity.

The correlation between cell operation and electrochemical methods for evaluating processes is always of interest, particularly because of consideration and limitations in using each approach. Recently Willsau and Heitbaum (34) studied and reviewed the elementary steps for ethanol oxidation on platinum in sulfuric acid using an isotopic labelling technique related to our cell operation. They emphasized the use of differential electrochemical mass spectroscopy (DEMS). This technique involves connecting the back side of a porous Teflon membrane to a mass spectrometer inlet system. The front side of the membrane covered with a platinum catalyst is in contact with $0.5 \mathrm{M}$ aqueous sulfuric acid electrolyte containing $10^{-2} M$ ethanol. This electrode construction is similar to that of an LAA-2 electrode so that related experiments can be compared.

(a)

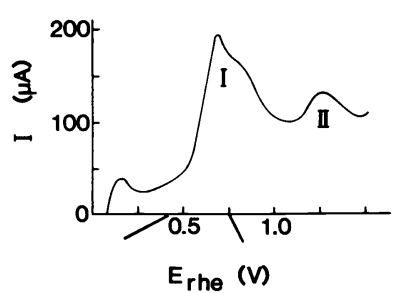

(b)

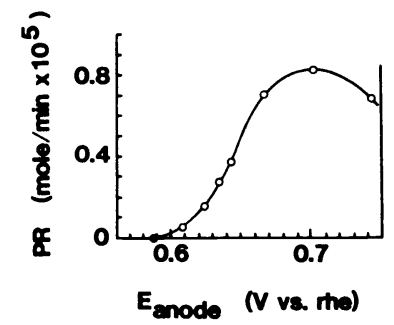

(c)

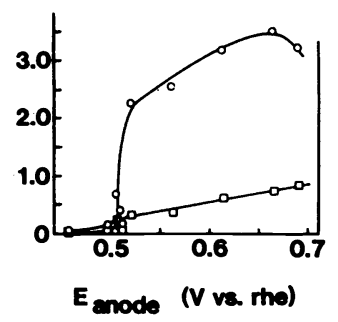

Fig. 7. Correlation between electrochemical methods and cell operation;

(a): forward scan of cyclic voltammogram on a DEMS Pt electrode in $10^{-2} \mathrm{M}$ ethanol, $0.5 \mathrm{M}$ aqueous $\mathrm{H}_{2} \mathrm{SO}_{4}, \mathrm{v}=3.125 \mathrm{mV} \mathrm{s}^{-1}$, after (34);

(b): Acetaldehyde production in $\mathrm{N}_{2}$ stream at LAA-2 electrode in contact with $1 \mathrm{M}$ ethanol in $3 \mathrm{M} \mathrm{H}_{2} \mathrm{SO}_{4}$;

(c): Acetaldehyde and carbon dioxide ( $\square$ ) production from an ethanol vapor fed cell (data of Exp. $V$ in Table 4) in same configuration as (b); $3 \mathrm{M} \mathrm{H}_{2} \mathrm{SO}_{4}$ electrolyte.

Some data for the forward part of the anodic scan of a cyclic voltammogram from the DEMS study are represented as Curve (a) in Figure 7 . It was shown that a maximum in acetaldehyde production roughly corresponded to the maximum in Peak I of Figure 7 . The corresponding study (Experiment III, Table 4) was not conducted with a reference electrode but with the well characterized LAA-2 electrodes. From previous studies ( 35 ) we could estimate the potential of the oxidizing ethanol electrode in an electrogenerative cell since cell resistance and the polarization at the oxygen electrode within $\pm 0.02 \mathrm{~V}$ were known. Curve (b) of Figure 7 represents the results for acetaldehyde production in a corresponding voltage range from a 1 M solution of ethanol in 3 M sulfuric acid solution. It is apparent that the maximum in acetaldehyde production in the cell then corresponds to the region of maximum acetaldehyde production using the DEMS method. However, the reason for the maximum in the electrogenerative production is different. With production data obtained over a time period of three to five minutes at slightly above $0.7 \mathrm{~V}$ deep oxidation begins to occur at the oxidizing platinum anode. Instead of the reversible metal surface oxidation which occurs with transient methods the surface oxidation begins to affect the metal catalyst. The oxidation eventually results in catalyst inactivity. This inactivity could be due to carbonaceous deposits but is probably a result of stable surface platinum oxide formation. Thus there is a lower limit for the operating voltage. As cell voltage decreases the anode potential becomes more positive approaching the potential of the polarized oxygen electrode.

The initiating oxidizing reaction appears to be

$$
\mathrm{CH}_{3} \mathrm{CH}_{2} \mathrm{OH}+\left(\mathrm{CH}_{3} \mathrm{CHOH}\right)_{\text {ads }}+\mathrm{H}^{+}+e
$$

followed by the loss of a proton and electron to give acetaldehyde. The simultaneous production of carbon dioxide has been observed by Heitbaum (34) and us. In this particular 
experiment, little carbon dioxide production is reported and gas formation in the electroly te was not monftored. However, such production as shown in Table 1 is more readily observed in a vapor fed cell.

Curves (c) of Figure 7 show acetaldehyde production as well as carbon dioxide in the vapor effluent of a vapor fed cell operated at $38^{\circ} \mathrm{C}$. This is Experiment $V$ with a nitrogen flow rate of about $59.4 \mathrm{cc} / \mathrm{min}$. The four-fold increase in production rate over that of Curve (b) is due to vapor fed alcohol which presumably displaces partially oxidized carbonaceous species from the catalyst surface. While there is a maximum in acetaldehyde production, there is an increase in carbon dioxide production in this range leading to decreased acetaldehyde production and selectivity at higher potentials. This can be explained again by platinum oxide formation which participates in the oxidation of the a lcohol derived carbonaceous species. Of central importance is the high acetaldehyde production rate of the vapor fed anode relative to the rate with $1 \mathrm{M}$ ethanol dissolved in the electrolyte. The highest production rate for acetaldehyde here is a heated cell in Experiment VI. The feed is nitrogen at $59 \mathrm{cc} / \mathrm{min}$ saturated with ethanol from a 75-25 ethanol-water mixture kept at $36^{\circ} \mathrm{C}$. Under these conditions, single pass conversions of the order of 0.4 are achieved with 61 percent of current accountability arising from acetaldehyde production and one or two percent of the ethanol converted to carbon dioxide. The current accountability of the order of 75 percent indicates that the majority of oxidation product have been identified. Some carbon dioxide and acetaldehyde may be produced and transported to the electrolyte side of the electrode (see Figure 5).

Experiment VIII of Table 4 is reported to illustrate substantial carbon dioxide production relative to acetaldehyde. Since the feed is only 25 percent ethanol, it could appear that total oxidation at the anode is enhanced by high water vapor concentrations. The continued anode reaction can be represented by

$$
\left(\mathrm{C}_{2} \mathrm{H}_{4} \mathrm{OH}\right)_{\mathrm{ads}}+3 \mathrm{H}_{2} \mathrm{O}+\mathrm{CO}_{2}+11 \mathrm{H}^{+}+11 \mathrm{e}
$$

The high carbon dioxide production rate and limited acetaldehyde production with the limited molar feed rate of ethanol in Experiment IV of Table 4 when compared to Experiment $v$ illustrates in another manner enhanced total oxidation of ethanol. These results suggest that consecutive reactions (such as $A \rightarrow B \rightarrow C$ ) a re involved in a significant fraction of the oxidation. The intermediate may or may not be surface bound. However, lower residence times favor acetaldehyde production. On the basis of a comparison of Experiments VI and VII of Table 4, it is not possible to select an optimum rich alcohol-water vapor $m i x$ for feeding to the electrogenerative reactor. The alcohol oxidation experiments are at an early stage but given the parameters available in reactor design and operation as well as catalyst design, it appears that a viable alcohol oxidation process could be developed.

\section{CONCLUSION}

A number of simple organic electrogenerative processes have been discussed in varying amounts of detall. Parallel to this a variety of techniques and approaches to studying these processes have been presented. Upon review it is surprising that so little has been done with electrogenerative processes. Some of the most interesting processes suggested in Table 1 have not been pursued to any significant extent. Of those listed, implementation of the oxidation of ethylene to ethylene glycol and reduction of nitrobenzene to aniline would involve large scale production. With higher currents, electrogenerative halogenations and halohydrin syntheses would be more appealing.

The organic electrogenerative processes considered to date are relatively elementary; more sophisticated processes can be expected to emerge in the future. Design and production of simple laboratory scale electrogenerative reactor equipment would bridge a gap between electrocatalysis and chemical practice generally. Possibilities for electrocatalyst deve1opment are great. Because of the foregoing considerations and the inherent appeal of utilizing an energy resource which remains unexploited, the exothermic energy of reaction, research with electrogenerative and related processes can be expected to grow in the next decade.

\section{Acknowledgement}

We thank the National Science Foundation, the University of Wisconsin and the Electrohol Corporation for support of this work. 


\section{REFERENCES}

(1) W. L̈̈b, Chem Ber, 29, 1390, 1894 (1896).

(2) H. A. Liebhafsky and E. J. Cairns, "Fuel Cells and Fuel Batteries", J. Wiley, New York (1968).

(3) W. Vielstich, "Fuel Cells", Wiley-Interscience, N.Y. (1970).

(4) E. Baur and J. Tobler, Z. Elektrochem, 32(3), 169 (1933).

(5) S. H. Langer and G. P. Sakellaropoulos, Ind Eng Chem Proc Des, 18, 567 (1979).

(6) S. H. Langer, P. H. Kilner, S. Floyd, and R. M. Spotnitz, Proceedings of the 161 st Electrochemical Society Meeting, Montrea1, Quebec, Canada, May 9-14, 1982. Symposium on Electrochemical Processes and Plant Design 1983, R. C. Alkire, T. R. Beck and R. D. Varjian, Eds.; Proceedings 83-6, The Electrochemical Society; p. 42 .

(7) S. H. Langer and José A. Colucci-Rios, CHEMTECH, 15(4), 226 (1985).

(8) F. Beck, International Chemical Engineering, $19(1), 1$ (1979).

(9) M. D. Birkett, A. T. Kuhn, and G. C. Bond in "Catalysis", G. C. Bond and G. Webb, Eds., Vol. 6, p. 61, The Royal Society of Chemistry, London (1983).

(10) Proceeding of Symposium on the Chemistry and Physics of Electrocatalysis, J. D. E. McIntire, M. J. Weaver and E. B. Yeager, Eds., 84-12, The Electrochemical Society, Pennington, N.J. (1984).

(11) G. P. Sakellaropoulos, Advances in Catalysis, W. K. Hall and H. Pines, Eds., 30 , Academic Press, New York, 1981.

(12) S. H. Langer and H. P. Landi, J Am Chem Soc, 86, 4694 (1964).

(13) S. H. Langer and G. P. Sakellaropoulos, J. Electrochem Soc, $122(12), 1619$ (1975).

(14) S. H. Langer, A. D. Miller, and S. J. Pietsch, Appl Chem Biotechnol, 27, 176 (1977).

(15) H. J. Davitt and L. F. Albright, J Electrochem Soc, 118, 236 (1971).

(16) S. H. Langer, I. Feiz, and C. P. Quinn, J Am Chem Soc, 93, 1097 (1971); 97,4786 (1975).

(17) H. Kita, Isr J Chem, 18, 152 (1979).

(18) A. Wieckowski, S. D. Rosasco, G. N. Salaita, A. Hubbard, B. E. Bent, F. Zaera, D. Godbey, and G. A. Somorjai, J Am Chem Soc, 107, 5910 (1985).

(19) G. P. Sakellaropou los and S. H. Langer, AIChE J, 24, 1115 (1978).

(20) G. P. Sakellaropoulos and S. H. Langer, J Catal, 67,77 (1981).

(21) S. J. Pietsch and S. H. Langer, AIChE Symp Ser No 185, 51 (1979).

(22) S. J. Pietsch, "Electrogenerative Halogenation of Olefins", PhD Thesis, University of Wisconsin-Madison (1978).

(23) S. J. Pietsch and S. H. Langer, Extended Abstracts 157 th Electrochemical Society Meeting, 非52, St. Louis, Missouri, May 11-16, The Electrochemical Society, 1980, pp. 1108; 1109 .

(24a) A. T. Kuhn and P. M. Wright, Electroanal Chem and Interfacial Electrochem, 41,329 (1973).

b) J. S. Mayell and S. H. Langer, J Electrochem Soc, 111, 438 (1964).

(25) S. H. Langer, A. D. Miller, and S. J. Pietsch, J Applied Chem Biotech, 27, 176 (1977).

(26) A. D. Miller and S. H. Langer, J Electrochem Soc, 120, 1615 (1973).

(27) S. H. Langer and S. Yurchak, J Electrochem Soc, $11 \frac{16}{16}, 1228$ (1969).

(28) G. P. Sakellaropoulos and S. H. Langer, J Catalysis, 44, 25 (1976).

(29) H. Kita and H. Nakajima, Electrochim Acta, 31, 193 (1986).

(30) J. N. Michaels and C. G. Vayenas, J Electrochem Soc, 131(11), 2544 (1984).

(31) R. L. Pesselman, T. M. Meshbesher, S. Floyd, and S. H. Langer, Chem Eng Commun, 38 , 265 (1985).

(32) T. M. Meshbesher, US Patent No. 4,347,109 (Aug 31, 1982).

(33) K. V. Rao and C. B. Roy, Indian J Chem, 19A, 840 (1980).

(34) J. Willsau and J. Heitbaum, J Electroanal Chem, 194, 27 (1985).

(35) R. G. Haldeman, W. P. Colman, S. H. Langer, and W. A. Barber, Adv Chem Series, 非7, American Chemical Society, 1965, pp 106-115 